\title{
ZBIOROWY ZARZĄD PRAWAMI AUTORSKIMI W ŚWIETLE DYREKTYWY PARLAMENTU EUROPEJSKIEGO I RADY NR 2014/26/UE Z DNIA 26 LUTEGO 2014 R. W SPRAWIE ZBIOROWEGO ZARZĄDZANIA PRAWAMI AUTORSKIMI I PRAWAMI POKREWNYMI*1
}

\section{PRACE PRZYGOTOWAWCZE}

Zbiorowy zarząd dziełami muzycznymi udostępnianymi online w ramach rynku wewnętrznego Unii Europejskiej znajduje się w kręgu zainteresowań organów Unii co najmniej od 2004 r. Inicjatywę w tej kwestii wyzwoliła rezolucja Parlamentu Europejskiego z 15 stycznia 2004 r. w sprawie wspólnotowych ram dla organizacji zbiorowego zarządzania w dziedzinie prawa autorskiego i praw pokrewnych ${ }^{2}$. W rezolucji tej Parlament wskazuje na rozwój technik cyfrowych rozpowszechniania utworów i konieczność dostosowania reguł zbiorowego zarządu do tych technik. Techniki te wymagają z kolei wypracowania metod dostępu do dzieł w skali światowej, a co najmniej licencji obejmujących teren całej UE. Odpowiedzią Komisji Europejskiej na tę rezolucję był komunikat KE z 16 kwietnia 2004 r. o zarządzaniu prawami autorskimi i pokrewnymi na Rynku Wewnętrznym ${ }^{3}$. W komunikacie tym podkreślono konieczność udzielania licencji dla utworów w postaci cyfrowej obejmujących całą UE. Licencja taka mogłaby zostać udzielona przez jedną organizację zbiorowego zarządzania (OZZ) dla całego rynku wewnętrznego. Profesjonalny nabywca licencji powinien mieć możliwość wyboru licencjodawcy spośród OZZ działających na całym rynku, niekoniecznie w kraju siedziby licencjodawcy. Ten sam postulat powtórzony był następnie w dokumencie Komisji z 11 października 2005 r. zwanym „Impact Assessment”“ oraz rezolucji Parlamentu Europej-

\footnotetext{
* Artykuł powstał w ramach projektu badawczego finansowanego ze środków Narodowego Centrum Nauki, przyznanych na podstawie decyzji nr DEC-2012/05/B/HS5/00835.

${ }^{1}$ Dyrektywa Parlamentu Europejskiego i Rady 2014/26/UE z 26 lutego 2014 r. w sprawie zbiorowego zarządzania prawami autorskimi i prawami pokrewnymi oraz udzielania licencji wieloterytorialnych dotyczących praw do utworów muzycznych do korzystania online na rynku wewnętrznym, Dz. Urz. UE L 84 z 20 marca 2014 r., s. 72 (dalej jako: dyrektywa 2014/26/UE).

${ }_{2}^{2}$ Dokument nr 2002/2274 (INI); Dz. Urz. UE C 92E z 16 kwietnia 2004 r., s. 425-432.

${ }^{3}$ COM (2004), 261 final, http://eur-lex.europa.eu/LexUriServ/LexUriServ.do?uri=COM:2004 :0261:FIN:EN:PDF.

${ }^{4}$ Commission Staff working document. Impact Assessment reforming cross-border collective management of copyright and related rights for legitimate online music services, Brussels
} 
skiego z 25 września 2008 r. w sprawie transgranicznego zbiorowego zarządzania prawami autorskimi i pokrewnymi w odniesieniu do legalnych usług muzycznych online ${ }^{5}$. Późniejszy komunikat Komisji zatytułowany „Jednolity rynek dla praw własności intelektualnej”“6 wyraża tę samą ideę.

Zdaniem Komisji transgraniczne świadczenie usług przez OZZ wymaga ujednolicenia zasad, na jakich działają te organizacje. Wstępne założenia, na których powinna się opierać taka organizacja, zostały już sformułowane w rekomendacji Komisji nr 2005/737/WE z 18 października 2005 r. ${ }^{7}$ o zbiorowym transgranicznym zarządzaniu prawami autorskimi i prawami pokrewnymi dla legalnego świadczenia usług muzycznych online. Rekomendacja ta jako dokument niewiążący została w różny sposób wdrożona w krajach członkowskich. Zakładała ona oparcie funkcjonowania OZZ na kilku zasadach podstawowych, jak: swoboda uprawnionych autorsko do wyboru właściwej OZZ, równego traktowania wszystkich uprawnionych przez OZZ oraz równego rozdziału pobieranych wynagrodzeń i opłat. Korzystajacy z repertuaru mieli uzyskiwać od OZZ pełną informację o stosowanych tabelach i o będącym w jej dyspozycji repertuarze. Rekomendacja zalecała także przyjęcie wspólnych standardów w zakresie rozliczania środków, należytej reprezentacji uprawnionych w organach OZZ oraz sposobów rozstrzygania sporów.

Rekomendacja spotkała się jednak z krytycznym przyjęciem ze strony Parlamentu Europejskiego. W rezolucji z 13 marca 2007 r. Parlament sugerował oparcie licencji muzycznych online na systemie umów o wzajemną reprezentację zawieranych przez OZZ. Umowy takie byłyby w zasadzie pozbawione sensu w świetle rekomendacji Komisji. Parlament sugerował wprowadzenie systemu kontrolowanej konkurencji między OZZ, pełną informację o stosowanych tabelach wynagrodzeń i warunkach licencji oraz równe traktowanie osób reprezentowanych i licencjobiorców. Podobną ocenę krytyczną propozycji Komisji zawierały także późniejsze rezolucje Parlamentu z 25 września 2008 r. ${ }^{8}$ i z 10 kwietnia 2008 r. ${ }^{9} \mathrm{~W}$ opiniach Parlamentu zalecenie z 18 maja 2005 r. mogło prowadzić do powstania dominacji na rynku muzycznym dużych organizacji posiadajacych repertuar światowy ze szkodą dla mniejszych organizacji posiadajacych głównie repertuar narodowy. Tym samym dorobek artystyczny mniejszych państw zostanie zmajoryzowany przez repertuar, którym dysponują większe organizacje. Model taki może też prowadzić do obniżenia pobieranych stawek licencyjnych zamiast przyczyniać się do podniesienia efektywności zarządzania prawami.

11.10.2005, SEC (2005), 1254, http://ec.europa.eu/internal_market/copyright/docs/management/ sec_2005_1254_en.pdf.

${ }_{5}^{5}$ 2010/C8E/19, http://eur-lex.europa.eu/LexUriServ/LexUriServ.do?uri=OJ:C:2010:008E:FUL L:PL:PDF; http://www.europarl.europa.eu/sides/getDoc.do?pubRef=-//EP//TEXT+TA+P6-TA-20080462+0+DOC+XML+ V0//EN.

${ }^{6}$ A Single Market for Intellectual Property Rights (...) COM (2011), 287 final z 24 maja 2011 r., http://ec.europa.eu/ internal_market/copyright/docs/ipr_strategy/COM_2011_287_en.pdf.

${ }^{7}$ Dz. Urz. UE L 376/54 z 21 października 2005 r.

${ }^{8}$ Por. wyżej przyp. 5.

${ }^{9}$ Rezolucja o przemysłach rozrywkowych w Europie (...), Dz. Urz. WE C 247, s. E/25 z 15 października 2009 r.; Rezolucja o europejskim kalendarzu kulturalnym w świecie globalizacji, Dz. Urz. WE C 247 z 15 października 2009 r., s. E/32. 


\section{PROJEKT DYREKTYWY}

Aby zrealizować powyższe założenia, Komisja sformułowała 11 lipca 2012 r. propozycję dyrektywy Parlamentu Europejskiego i Rady dotycząca zbiorowego zarządzania prawami autorskimi i prawami pokrewnymi i udzielania licencji transgranicznych obejmujących szereg terytoriów (multi-territorial) $\mathrm{w}$ odniesieniu do praw do utworów muzycznych do korzystania z nich online na rynku wewnętrznym ${ }^{10}$. Wbrew swemu tytułowi proponowana dyrektywa dotyczyła usług online w odniesieniu do utworów muzycznych tylko w ograniczonym zakresie. Do tych usług odnosiły się: tytuł III (art. 21-33) oraz art. 36 i art. 40 projektu. Pozostałe przepisy projektu dyrektywy (na ogólna ich liczbę 44) były poświęcone zbiorowemu zarządzaniu w ogólności. Był to zatem pierwszy dokument UE bezpośrednio poświęcony zbiorowemu zarządzaniu prawami autorskimi i pokrewnymi. Dotychczasowe wzmianki o OZZ $\mathrm{w}$ szeregu dyrektywach ${ }^{11}$ miały incydentalny charakter i nie dotyczyły samej struktury i funkcjonowania OZZ.

Projekt dyrektywy wychodził z założenia, że OZZ podlegaja w ogólności przepisom dyrektywy 2006/123/WE z 12 grudnia 2006 r. o usługach na Rynku Wewnętrznym ${ }^{12}$, opierającej się na traktatowym założeniu swobody świadczenia usług na tym rynku. Swoboda ta dotyczy zarówno oferowania przez OZZ usług reprezentacji, w tym także twórcom przebywającym lub prowadzącym działalność w innych krajach członkowskich, jak i udzielania licencji korzystającym z utworów, którzy mają siedzibę lub działają w innych krajach członkowskich niż kraj siedziby organizacji.

Opracowanie projektu poprzedziły konsultacje ze wszystkimi zainteresowanymi osobami i organizacjami, poczynając od autorów, wydawców, artystów wykonawców, producentów, OZZ, licencjobiorców, konsumentów, a na jednostkach publicznoprawnych kończąc. Konsultacje te trwały od października 2009 r., a 23 kwietnia 2010 r. Komisja zorganizowała publiczne przesłuchanie, w którym brało udział ok. 300 uczestników. Ostatecznym efektem tych konsultacji był przedłożony projekt. Projekt wzbudził podobne zastrzeżenia co rekomendacja Komisji z 18 października 2005 r. Zastrzeżenia te zawiera m.in. uchwała Sejmu RP z 12 października 2012 r. ${ }^{13}$ Uchwała zarzucała pro-

${ }^{10}$ Proposal for a directive of the European Parliament and the Council on collective management of copyright and related rights and multi-territorial licensing of rights in musical works for online uses in the internal market, Bruksela 11 lipca 2012 r., COM (2012), 372 final, 2012/0180 (COD), http://eur-lex.europa.eu/LexUriServ/LexUriServ.do?uri=COM:2012:0372:FIN:EN:PDF. O projekcie dyrektywy pisali: M. Kępiński, Nowe propozycje Komisji Europejskiej i Parlamentu w sprawie zbiorowego zarzadzania prawami autorskimi do dzieł muzycznych udostepnianych online, w: K. Szczepanowska-Kozłowska (red.), Oblicza prawa cywilnego. Ksiega jubileuszowa dedykowana Profesorowi Janowi Bteszyńskiemu, Warszawa 2013, s. 226-233, i E. Traple, Blaski i cienie $i d e i$ one stop shop $w$ odniesieniu do zbiorowego zarzqdu prawami autorskimi. Uwagi na gruncie projektu dyrektywy $w$ sprawie zbiorowego zarzadu prawami autorskimi $i$ pokrewnymi, w: K. Szczepanowska-Kozłowska (red.), op. cit., s. 535-559.

11 Por. np. dyrektywa 92/100; dyrektywa 2001/29/WE; dyrektywa 93/83; dyrektywa 2006/115/WE.

12 Dz. Urz. UE L 376/36 z 27 grudnia 2006 r.

13 M.P. z 25 października 2012 r., poz. 794 oraz załącznik do uchwały, ibidem. 
jektowi dyrektywy sprzeczność z zasadą pomocniczości, gdyż jej cel w postaci większej przejrzystości w funkcjonowaniu OZZ może być lepiej osiagnięty na poziomie prawa krajowego. Ponadto projekt nakładał na OZZ nadmierne obowiązki, obniżając poziom wolności gospodarczej, którą dysponują te organizacje. Ponadto zarzucono projektowi, że:

- nakłada na OZZ bliżej niesprecyzowane obowiązki kontraktowania;

- zobowiązuje do ukształtowania ustroju OZZ w sposób właściwy dla prawa spółek kapitałowych, co jest sprzeczne z zasadą ich funkcjonowania jako stowarzyszeń;

- może obniżyć poziom ochrony praw autorskich przez zezwolenie na delegowanie kompetencji OZZ na inne podmioty.

\section{DEFINICJA OZZ W DYREKTYWIE}

Mimo tych i innych zastrzeżeń omawiany projekt stał się bez większych zmian ostatecznym tekstem dyrektywy ${ }^{14}$. Zawiera on szereg definicji, z których podstawową wydaje się sama definicja OZZ (collecting society). Taka organizacja oznacza każdą organizację:

1) która $z$ mocy prawa lub $w$ drodze powierzenia, licencji lub innego stosunku umownego jest upoważniona przez więcej niż jeden podmiot autorsko uprawniony do zarządzania prawami autorskimi i pokrewnymi dla zbiorowej korzyści tych podmiotów oraz

2) dla której zarządzanie tymi prawami stanowi wyłączny albo główny przedmiot jej działalności, o ile:

3) należy do swoich członków lub jest przez nich kontrolowana, lub

4) jest organizacją nienastawioną na zysk.

Definicja ta pozwala na objęcie swym zakresem wszystkich znanych w Europie form organizacyjnych OZZ. Mogą to być w szczególności spółki z ograniczoną odpowiedzialnościa, stowarzyszenia czy fundacje. Niewątpliwie polskie OZZ w szczególnej formie stowarzyszenia podlegającego nadzorowi Ministra Kultury i Dziedzictwa Narodowego odpowiadaja powyższej definicji i nie narzuca ona konieczności zmian w polskim prawie autorskim w kwestii formy organizacyjnej OZZ. Formuła powyższa pozwala także na objęcie pojęciem zbiorowego zarządzania wszystkich form uzyskania przez OZZ zarządu utworami spotykane w praktyce polskiej, a mianowicie przeniesienie praw autorskich na OZZ, udzielenie OZZ upoważnienia do zarządzania prawami autorskimi czy wreszcie szeroko rozumiane negotiorum gestio, które można podciąnąć albo

${ }^{14}$ Dyrektywa 2014/26/UE, s. 72. O dyrektywie por. liczne uwagi M. Zaremby, Prawna regulacja krajowego rynku zbiorowego zarzqdzania prawami do muzyki, Warszawa 2014; oraz M. Bukowski, w: D. Flisak (red.), Prawo autorskie i prawa pokrewne. Komentarz Lex, Warszawa 2015, s. $1270-1273$. 
pod określenie innego stosunku umownego (any other contractual arrangement), albo pod działanie z mocy przepisów prawa.

Przepisy dotyczące organizacji OZZ są liczne (18 artykułów) i stanowią zupełną nowość w prawie unijnym. Będą one niewątpliwie wymagały nieomal w całości implementacji do naszego prawa autorskiego. Jako drugą opcję można rozważyć wyłączenie przepisów dotyczących OZZ w odrębną ustawę na wzór niemiecki. Polski model regulacji prawa własności intelektualnej przemawia raczej za włączeniem nowych przepisów do prawa autorskiego, podobnie jak to uczyniono z przepisami o charakterze organizacyjnym dotyczacymi Urzędu Patentowego w prawie własności przemysłowej.

\section{OZZ A JEJ CZŁONKOWIE}

W przepisach dotyczących OZZ (art. 4-22 dyrektywy) zwraca uwagę to, że organizacja ma działać w najlepszym interesie lub z najpełniejszą korzyścia (in the best interest) swoich członków. Takiego sformułowania brak wyraźnie wysłowionego w polskiej ustawie o prawie autorskim, chociaż można uznać, że w tym kierunku zmierza praktyka statutowa OZZ. Jest jednak zastanawiające, że przepisy dyrektywy opierają się przede wszystkim na modelu członkostwa w organizacji i nie regulują bliżej możliwości powierzenia OZZ praw bez przyjmowania przez powierzającego obowiązków członka tej organizacji, co często występuje w naszej krajowej praktyce. O obowiązkach OZZ względem nieczłonków stanowi jednak art. 7 dyrektywy nakazujacy OZZ stosować przepisy art. 6 ust. 4, art. 20, art. 29 ust. 2 i art. 33 także w odniesieniu do podmiotów uprawnionych, które nie są członkami OZZ, a pozostaja z tymi organizacjami w bezpośrednich stosunkach prawnych. Powyższe przepisy dotyczą sposobu komunikowania się z takimi osobami za pośrednictwem elektronicznych środków komunikacji, dostarczania im niezbędnych informacji, w tym o umowach o wzajemnej reprezentacji oraz o prawie wnoszenia skarg w sprawach działalności organizacji.

Zasadniczą nowością w dyrektywie jest założenie swobody powierzania przez uprawnionych autorsko swoich praw OZZ (art. 5 ust. 2). Od uprawnionego zależy:

1) zakres powierzanych praw;

2) określenie utworów, których powierzenie dotyczy;

3) określenie kraju lub krajów UE, których teren powierzenie obejmuje.

Powierzenie powyższe może nastapić na rzecz dowolnie wybranej przez uprawnionego autorsko OZZ niezależnie od kraju:

1) w którym jest siedziba lub do którego przynależy OZZ, albo

2) którego obywatelstwo lub miejsce zamieszkania posiada uprawniony autorsko.

Ze swoboda powierzania praw przez uprawnionych autorsko skorelowany jest obowiązek podejmowania się zarządu tymi prawami nałożony na wszyst- 
kie OZZ pod warunkiem, że zarządzanie daną kategorią praw wchodzi w zakres działalności OZZ. Temu postanowieniu odpowiada art. 106 ust. 3 pr.aut. ${ }^{15}$

Powyższa zasada swobody powierzenia praw i świadczenia usług zarządzania prawami autorskimi winna być wyrażona ustawowo i nie wystarczy ja wprowadzić do statutów OZZ, nawet gdyby właściwy organ nadzorczy kontrolował z tego punktu widzenia statuty tych organizacji. Swoboda powierzania praw przez uprawnionego autorsko dowolnej OZZ zakłada także możliwość cofnięcia upoważnienia do zarządzania. Oświadczenie o wypowiedzeniu upoważnienia powinno być możliwe ze skutkiem na nie później niż 6 miesięcy od jego złożenia lub ewentualnie na koniec roku obrotowego.

Dyrektywa przewiduje, że statuty organizacji powinny zapewniać ich członkom należyty wpływ na procesy decyzyjne. Co najmniej raz w roku powinny być zwoływane walne zgromadzenia członków o przewidzianym w dyrektywie zakresie kompetencji (art. 8 ust. 3). Organizacje maja ponadto posiadać zarząd oraz organ nadzorczy. Wyjątkowo, jeżeli OZZ nie ma walnego zgromadzenia ze względu na swoją formę prawna, jego rolę wypełniać powinien organ nadzorczy (art. 8 ust. 12).

\section{FINANSE OZZ}

Artykuły 11-13 poświęcone są finansom OZZ. Nie mają one swoich odpowiedników w aktualnym polskim prawie i wymagać będą ich transpozycji do nowej ustawy. Zasadą ogólną jest obowiązek należytej staranności w gromadzeniu wynagrodzeń autorskich. W tym celu OZZ mają obowiązek oddzielnego prowadzenia rachunków dla przychodów z praw autorskich i przychodów uzyskiwanych z innych źródeł. Organizacje nie mają prawa wykorzystywać na własne potrzeby wpływów z tytułu praw autorskich oraz wpływów z inwestycji dokonywanych $\mathrm{z}$ własnych środków. Wyjątek stanowią tutaj tylko własne koszty zarządzania. O tych kosztach każdy członek i powierzający swe prawa powinien być co najmniej raz w roku informowany. Podobnie uprawnieni powinni być informowani o potrąceniach dokonywanych na cele socjalne, kulturalne i edukacyjne. Organizacje mają obowiązek regularnie i z należytą starannością rozdzielać uzyskane wynagrodzenia pomiędzy osoby uprawnione. Taki rozdział środków powinien następować z reguły w ciągu dziewięciu miesięcy od końca roku, w którym wynagrodzenia zostały pobrane. Środki nierozdzielone w powyższym trybie w ciagu 5 lat mogą być rozdysponowane przez walne zgromadzenie członków OZZ. Podobne zasady obowiąują względem uprawnionych niebędących członkami, których OZZ reprezentuja. Uprawnieni autorsko reprezentowani w tym trybie nie mogą być traktowani gorzej niż członkowie organizacji w zakresie stosowanych tabel wynagrodzeń, kosztów zarządzania, warunków pobierania i rozdziału wynagrodzeń. Warto zauważyć, że powyższą zasadę wyraża w ogólnych sformułowaniach także art. 106 ust. 1 pr.aut. Prze-

15 Ustawa z 4 lutego 1994 r. o prawie autorskim i prawach pokrewnych, Dz. U. 1994, Nr 24, poz. 83 (dalej jako: pr.aut.). 
pis ten wymagałby jednak rozwinięcia w kwestach zarządzania funduszami będącymi w dyspozycji OZZ. Obecna praktyka wskazuje, że nieczłonkowie zwykle nie mają dostępu do funduszy o charakterze socjalnym.

W relacjach z korzystającymi z utworów, a więc z licencjobiorcami, OZZ powinny ustalać warunki licencji na podstawie obiektywnych kryteriów, w szczególności wynikające ze stosowanych stawek. Stawki te winny uwzględniać gospodarcze znaczenie praw autorskich i pokrewnych objętych licencja oraz wartość usług świadczonych przez OZZ. Tym kryteriom czyni, jak się wydaje, zadość obecna treść art. 110 pr.aut.

\section{OBOWIĄZKI OZZ}

Niezbyt jasno sa natomiast sformułowane w dyrektywie przepisy dotyczące obowiązku udzielania licencji korzystającym z utworów. Artykuł 16 ust. 3 przewiduje, że OZZ po otrzymaniu od potencjalnego licencjobiorcy niezbędnych do zawarcia licencji informacji oferuje mu licencję albo wyjaśnia, dlaczego nie zamierza udzielić licencji. Przepis ten nie określa zatem jasno, czy OZZ jest zobowiązana do udzielenia licencji, jeżeli uzyskała niezbędne informacje. W preambule dyrektywy (akapit 31) mowa jest jedynie o obowiąku udzielenia bez zbędnej zwłoki odpowiedzi na wniosek potencjalnego licencjobiorcy dotyczący udzielenia licencji. Jak się wydaje, przepis art. 106 ust. 2 pr.aut., który obowiązek taki wyraźnie formułuje, nie pozostaje w sprzeczności z dyrektywa. Wręcz przeciwnie, sformułowania dyrektywy zdają się stanowić zachętę do wyraźnego przyjęcia obowiązku udzielenia licencji przez OZZ w prawie krajowym.

Istotne znaczenie mają w dyrektywie przepisy o obowiązkach informacyjnych OZZ. Obowiązki te powinny OZZ realizować głównie w drodze elektronicznej. Informacje te dotyczą przede wszystkim kwot pobranych i należnych osobom uprawnionym oraz potrąceń dokonywanych przez OZZ w celu pokrycia kosztów zbiorowego zarządzania. Organizacja winna też na żądanie udostępniać wzory umów licencyjnych, posiadany repertuar i listę umów o wzajemnej reprezentacji z innymi OZZ. Na swojej stronie internetowej każda organizacja powinna udostępniać istotne informacje o sobie (art. 21 dyrektywy), jak: statut, członków zarządu, warunki członkostwa, zasady rozdziału środków.

$\mathrm{Na}$ stronie internetowej OZZ powinno być publikowane roczne sprawozdanie z jej działalności. Sprawozdanie to powinno informować każdego zainteresowanego o sytuacji finansowej OZZ oraz o działalności organizacji w roku objętym sprawozdaniem. Pełna lista informacji objętych sprawozdaniem obejmuje całe dwie strony załącznika do dyrektywy. Wydaje się, że obecne postanowienia art. 104 ust. $3^{1}-3^{5}$ pr.aut. w ogólności czynia zadość powyższym postanowieniom. Można założyć, że szczegóły sprawozdania rocznego odpowiadające postanowieniom art. 21 dyrektywy i załącznika do niej mogłyby zostać ujęte w przewidzianym w art. 104 ust. $3^{5}$ pr.aut. rozporządzeniu ministra właściwego ds. kultury i ochrony dziedzictwa narodowego. 


\section{UDZIELANIE LICENCJI TRANSGRANICZNYCH}

Zgodnie z tytułem dyrektywy drugą część jej postanowień zajmują przepisy dotyczace udzielania przez OZZ transgranicznych licencji (multi-territorial licences) online dla utworów muzycznych. Licencje online rozumiane są w projekcie jako obejmujące prawo publicznego udostępniania utworów muzycznych i prawo podawania ich do publicznej wiadomości w znaczeniu przewidzianym w art. 3 dyrektywy 2001/29/WE z 22 maja 2001 r. w sprawie harmonizacji niektórych aspektów praw autorskich i praw pokrewnych w społeczeństwie informacyjnym ${ }^{16}$. Dyrektywa 2001/29/WE wymaga od korzystajaccego z utworów $\mathrm{w}$ trybie online uzyskania licencji od uprawnionego autorsko. Takimi uprawnionymi do udzielania licencji są w szczególności OZZ upoważnione do zbiorowego zarządzania prawami autorskimi i pokrewnymi w odniesieniu do dzieł muzycznych. Dla korzystających z utworów, którzy chcą je udostępniać publiczności, jest ogromnym ułatwieniem usługa dostępu do całego repertuaru dzieł muzycznych będącego w dyspozycji OZZ. Celem dyrektywy jest stworzenie warunków niezbędnych do tego, aby udzielanie licencji transgranicznych na jednolitym rynku w UE było jak najbardziej ułatwione. Warunki te w postanowieniach dyrektywy powinny m.in. obejmować:

- dostępność informacji o repertuarze OZZ;

- umożliwienie łączenia repertuaru muzycznego przez OZZ w celu ułatwienia udzielenia jednej licencji na cały repertuar podmiotom oferujacym usługi korzystania z muzyki online;

- obowiązek podjęcia się przez OZZ reprezentacji repertuaru każdej organizacji, która sama nie ma warunków do udzielania transgranicznych licencji;

- dostępność informacji o przepływach finansowych związanych z korzystaniem z praw autorskich do utworów muzycznych;

- dostępność informacji o uprawnionych autorsko, których OZZ ma prawo reprezentować w określonym kraju.

Spełnienie powyższych warunków wymaga rozbudowania odpowiedniego zaplecza informatycznego w postaci nowoczesnych baz danych gromadzących takie informacje. Na podstawie powyższych informacji OZZ powinny wystawiać usługodawcom internetowych usług muzycznych faktury w drodze elektronicznej. Pobrane w ten sposób wynagrodzenia powinny być dokładnie i terminowo wypłacane na rzecz uprawnionych autorsko.

Ważnym postanowieniem jest przepis art. 29 dyrektywy, który przewiduje, że umowy o wzajemną reprezentację zawierane pomiędzy dwiema OZZ, a dotyczące licencji transgranicznych do dzieł muzycznych online będących w repertuarze OZZ, powinny sprowadzać się tylko do udzielania licencji niewyłącznych. Powodem takiego rozwiazzania jest ułatwienie dostępu do repertuaru, którym dysponuje OZZ, wszystkim podmiotom świadczącym usługi udostępniania muzyki online. Ponadto niewyłączność licencji ma także ułatwić zawieranie umów o wzajemną reprezentację między OZZ. Rozwiązanie to równocześnie potwier-

16 Dz. Urz. UE L 167 z 22 czerwca 2001 r. 
dza założenie, że nie wszystkie OZZ będą w stanie spełniać warunki dyrektywy do bezpośredniego udzielania transgranicznych licencji online. Organizacje niespełniające tych warunków będą zatem zmuszone do powierzania zawierania umów w tym zakresie tym OZZ, które warunki te spełniaja.

\section{ROZSTRZYGANIE SPORÓW}

Ostatnia część dyrektywy dotyczy rozstrzygania sporów pomiędzy OZZ a jej członkami i osobami powierzajacymi jej swoje prawa autorskie oraz między OZZ a licencjobiorcami praw autorskich do muzyki online. W przypadku sporów pomiędzy OZZ a jej członkami lub powierzajacymi swoje prawa podmiotami to na OZZ zostaje nałożony obowiązek oferowania właściwych procedur zapewniających szybki i efektywny sposób rozstrzygania takich sporów. Sadzić można, że wystarczy w tym zakresie wprowadzić właściwe postanowienia $\mathrm{w}$ statutach organizacji. Musiałyby one w tych kwestiach podlegać kontroli ze strony organów nadzoru.

Spory między OZZ a korzystającymi z utworów dotyczące warunków umów licencyjnych, stawek wynagrodzeń i odmowy udzielania licencji powinny podlegać rozstrzygnięciu przez sąd albo przez inny niezależny i bezstronny organ. Oznacza to zatem dopuszczalność także polubownego rozstrzygania takich sporów.

Natomiast niektóre spory OZZ z uprawnionymi autorsko, z licencjobiorcami świadczącymi usługi w odniesieniu do utworów muzycznych online i spory z innymi OZZ powinny podlegać sądownictwu polubownemu (art. 34 dyrektywy).

Powyższe postanowienia dotyczące rozstrzygania sporów w drodze sądowej lub polubownej będą wymagały przemyślenia przepisów prawa autorskiego w kwestiach kompetencji Komisji Prawa Autorskiego (KPA). Komisja nie jest bowiem sądem polubownym w ścisłym tego słowa znaczeniu, a jej decyzje maja charakter decyzji administracyjnych. Nie jest zatem w pełni jasne, czy funkcjonowanie KPA odpowiada wymogowi powołania sądownictwa polubownego, co przewiduje dyrektywa. Warto przy tym zauważyć, że dyrektywa przewiduje obowiąek poddania niektórych sporów sądownictwu polubownemu tylko w zakresie udzielania licencji transgranicznych online dotyczacych praw do utworów muzycznych. Ustawodawca krajowy będzie zatem musiał rozstrzygnać, czy takie ograniczenie przedmiotowe powyższych sporów jest uzasadnione i co za tym idzie - czy wymogi dotyczace sądownictwa polubownego nie powinny obejmować także wszystkich sporów z zakresu działania OZZ.

\section{PODSUMOWANIE}

Niewątpliwie omawiana dyrektywa stanowi wyzwanie dla ustawodawcy krajowego. W szeregu kwestii, szkicowo zarysowanych powyżej, trzeba będzie rozbudować przepisy prawa autorskiego dotyczące działalności OZZ. Prawdo- 
podobnie wzrosną także obowiązki nadzorcze Ministra Kultury i Dziedzictwa Narodowego. Być może Komisji Prawa Autorskiego trzeba będzie nadać w pewnym zakresie kształt instytucjonalnego sądu arbitrażowego lub powierzyć te zadania jednemu ze stałych sądów polubownych działających w naszym kraju. Wszystko to wymaga przedyskutowania niezbędnych zmian w polskim prawie autorskim.

Termin wprowadzenia przedstawionych powyżej skrótowo zmian w prawie autorskim nie jest odległy. Artykuł 43 dyrektywy przewiduje, że przepisy implementujace jej postanowienia do prawa krajowego powinny być wydane do 10 kwietnia 2016 r. Ponieważ w roku bieżącym (2015) mamy wybory parlamentarne, odpowiedni projekt nowych przepisów powinien trafić do Sejmu najpóźniej zaraz po ukonstytuowaniu się Sejmu nowej kadencji. Jest pewne, że wywoła on spore dyskusje, i stąd okres sześciu miesięcy na prace w komisjach sejmowych wydaje się potrzebny.

prof. dr hab. Marian Kepiński

Uniwersytet im. Adama Mickiewicza w Poznaniu

kpe@amu.edu.pl

\begin{abstract}
COLLECTIVE COPYRIGHT MANAGEMENT IN LIGHT OF DIRECTIVE 2014/26/EU
OF THE EUROPEAN PARLIAMENT AND THE COUNCIL OF 26 FEBRUARY 2014

ON COLLECTIVE MANAGEMENT OF COPYRIGHT AND RELATED RIGHTS
\end{abstract}

Sum mary

The paper deals with a recent EU directive regulating activities of collecting societies on the one hand, and granting multiterritorial online licences to musical works on the other hand. First, the 10-year long preparatory process is presented, followed by a discussion of the resulting directive. It is concluded that the definition of collective societies provided in the directive is not contrary to the provisions of Polish copyright law. Further in the paper, the relationships between collecting societies, their members, licensees and other collective management organisations are presented. It is also pointed out that collecting societies are obliged to secure equal treatment of all persons they represent as well as the licensees, and to maintain a transparent finance policy. They are also recommended to subject collective management disputes to arbitration. 